Jordina Sales-Carbonell

\title{
Jerome and Western Monasticism: Asceticism, Evergetism, and Orthodoxy in the Late $4^{\text {th }}$ Century Hispania
}

\section{Hieronim in zahodno meništvo: asketicizem, everge- tizem in ortodoksnost $v$ Hispaniji poznega 4. stoletja}

Abstract: Jerome had very little Hispanic epistolary correspondence. Nonetheless, the information contained in his few surviving letters gives us an idea of the essential nature of the first Hispanic monasticism - that related to aristocratic asceticism in a family milieu. Among other things, it was the economic basis for the foundation of monasteries throughout the Holy Land under the direct patronage of Jerome of Stridon. Lucinus and his wife Theodora were wealthy Baetican landowners who became active euergetes for the Christian cause and embraced an ascetic life under Jerome's influence. Lucinus sent conspicuous amounts of money to Jerome. He also sent a garment he had worn as a symbol of his conversion to monasticism, a decision Jerome endorsed and blessed when he replied by sending silicon garments for him and his wife, Theodora. Abigaus was a blind man who also converted to asceticism under the epistolary influence of Jerome. He appears to have been related to a proto-monastic community to which Lucinus and Theodora may have belonged. This is an exciting aspect that allows us to fully comprehend the beginnings of coenobitism in the western reaches of the Roman Empire. The portrait of a late $4^{\text {th }}$-century orthodox asceticism painted by Jerome's letters will be analyzed and compared with the information gleaned from the contemporary archaeological remains in Hispania impregnated by Priscillianism and other heterodox movements against which Jerome railed through epistolography from his base in the Holy Land.

Keywords: Hispania, monasticism, asceticism, orthodoxy, Christianization among the aristocracy, ecclesia in villa

Povz̨etek: Čeprav je Hieronimovih epistolarnih korespondentov iz Hispanije zelo malo, je iz nekaterih ohranjenih pisem kljub temu mogoče razbrati bistveno značilnost zgodnjega hispanskega meništva, ki je bilo povezano z aristokratskim asketicizmom družinske narave, to pa je med drugim prispevalo k ekonomski 
podlagi ustanavljanja samostanov v Sveti deželi pod vodstvom stridonskega pisca. Bogata betičanska veleposestnika, Lucin in žena Teodora, ki sta postala dejavna pri krščanski dobrodelnosti, sta pod Hieronimovim vplivom sprejela asketski način življenja. Lucin je Hieronimu poslal velik znesek denarja, obenem pa - kot simbol svojega sprejetja meniškega življenja - tudi volnen kos blaga; to je Hieronim pohvalil in blagoslovil, saj jima je nazaj tudi sam poslal kos blaga. Na drugi strani se zdi, da je slepi Abigaus, ki se je prav tako oklenil meništva pod vplivom Hieronimovih pisem, povezan s protomeniško skupnostjo, kateri sta morda pripadala tudi Lucin in Teodora, to pa lahko prispeva $\mathrm{k}$ boljšemu razumevanju cenobitskega meništva v zahodnem delu imperija. Članek obravnava ortodoksni asketicizem s konca 4. stoletja, kakor ga prikazujejo Hieronimova pisma, in ga primerja s sodobnimi dognanji glede (arheologije) hispanskega meništva, ki so ga pogosto zaznamovale tendence priscilijanizma in drugih heterodoksnih gibanj, proti katerim se je Hieronim iz Svete dežele boril s pismi.

Ključne besede: Hispania, meništvo, asketicizem, ortodoksnost, pokristjanjevanje aristokracije, ecclesia in villa

\section{Introduction}

This short paper will analyze various aspects deriving from the direct contact Jerome established with the first Hispanic monasticism ${ }^{1}$ (or, more specifically, the first Hispanic asceticism). ${ }^{2}$ As far as we know, Jerome never travelled to Hispania, and none of his texts or any third parties refers to it, either in a legendary or an apocryphal manner.

His presence on Hispanic soil came through his letters and the early dissemination and influence of his work. It should be framed within an initial general flow in which the 'Eastern Christian factor' reached the Iberian Peninsula almost exclusively in the form of literature $\left(4^{\text {th }}-5^{\text {th }}\right.$ centuries). It also arrived very occasionally through the presence of certain people who came with or at the invitation of Westerners who had previously travelled to the Holy Land.

This occurred in both Hispania and the rest of Western Europe. With Jerome, it can be seen; for example, in the presence among his circle of friends and acquaintances of Evagrius of Antioquia, an Eastern priest brought to Europe by Eusebius of Vercelli, who, during Jerome's youth, moved between Aquileia and Concordia.

This paper falls within the framework of the project: „Monastic Landscapes. Representations and virtualisations of Medieval Spiritual and Material Realities in the Western Mediterranean $\left(6^{\text {th }}-16^{\text {th }}\right.$ centuries)“ PGC2018-095350-B-I00.

2 The origin of Hispanic asceticism has already been dealt with masterfully by, among others, Díaz Martínez 1991 and Marcos Sánchez 2002. 
It would not be until later ( $6^{\text {th }}-7^{\text {th }}$ centuries) that the Oriental Christians, especially monks, physically moved westwards in general and to the Iberian Peninsula. ${ }^{3}$ This occurred for various reasons, none of which interests us here and will not go into this presentation. However, this research will focus on the stage during the last years of the Western Roman Empire and the influence exerted by Jerome on the first outbreaks of monasticism at its westernmost end.

\section{The Hispanic Religious Framework}

From the point of view of Christianity, the Hispania of the last decade of the $4^{\text {th }}$ century (the chronological framework in which we document the contact between Jerome and Hispanic asceticism) was a territory characterized by the proliferation of different heterodoxies (Escribano Paño 1990, 151-189), as also happened in the East and many other parts of the Empire. It is known that Jerome fought very actively and vehemently against many of these doctrinal positions (Jeanjean 1999).

In the historical framework of Jerome's lifetime, some of the primary heresies in Hispania were Arianism, Priscillianism, ${ }^{4}$ Gnosticism, Manichaeism, and Novatianism, even though the prefecture of Gaul (and therefore the Vicariate of the Hispanias) suffered the most extreme measures of religious totalitarianism applied by Emperor Maximus from 383. In this very messy, confused, and tense doctrinal environment, Hispanic Christians who devoted themselves to the ascetic way of life ${ }^{5}$ needed clear spiritual guidance, an aspect that does not always appear to have been satisfied by the local hierarchies (often precisely because they were immersed in their doctrinal struggles).

Some confusion and involuntary heterodoxy must have existed (and is verified in different sources) among Hispanic Christians, who were victims of pressure from the different positions mentioned above. Consequently, it is not surprising that the faithful and ascetic, in order to ensure the correct orthodoxy in their ascetic practices (un- or very little regulated in those initial moments of Western monasticism), would end up appealing to an exogenous, superior authority such as Jerome at this stage of their maturity for precise advice and instruction. Moreover, the fear of falling into heterodoxy and ending up like Priscillian (executed in 385, a few years before the Hispanic letters we comment on below) would probably have influenced the decision to be placed under the direct tutelage of a higher authority. ${ }^{6}$ This procedure had already been clearly established in other canonical documents, such as Pope Siricius' letter-decree to Bishop Himerius of Tarraco (Ep. 1.7 [PL 13, 1137-1141]), also in 385.

3 My article entitled „Syrian and other Eastern monks in Late Antique Hispania. Archaeological data“ will appear in a monograph Power, Conversion and Religious Leadership (Oxford: Oxford University Press).

4 A heresy for which Jerome had a particular aversion, e.g. Ep. 120.10.

5 Fontaine $(1979,28-53)$ analysed some years ago the ascetic model that had been brought from the East to the West and that, from the late $4^{\text {th }}$ century, had been installed in the villae of the aristocratic families converted to Christianity.

6 As Jerome himself confirms in his Ep. 75 addressed to a Hispanic ascetic. 
Additionally, Jerome's base in the Holy Land and its strategic installation next to the Nativity Church in Bethlehem gave him an unquestionable aura of fame and authority in the Christian world. That authority is known to have begun taking shape when he worked as a "secretary of Latin letters « for Pope Damasus in the 480s and began to surround himself with select Roman matrons prepared to devote themselves to asceticism under the guidance of their master. Finally, having overcome his problems in Jerusalem relating to Origenism (Bautista Valero 2013, 45-65), his steadfast struggle against the diverse heterodoxies of the period endowed him with the outstanding experience and authority to emerge as a universal reference for the Catholic orthodoxy of his time (Moreschini 1982, 61-71).

Returning to the Hispanic heterodoxies, perhaps the most influential of the time, Priscillianism, should be particularly highlighted, not only for its intrinsic importance but also for its apparent similarities to the way Jerome organized his disciples. Jerome, like Priscillian, surrounded himself mainly with women, aristocratic Roman matrons who sought in the charismatic figure the spiritual master who would guide their new ascetic status. ${ }^{7}$ Let us recall the first woman Jerome led to becoming a ,consecrated virgin': his sister. This led to family tensions, and that, together with the resignation of his career in the court of Valentinian I, was the straw that broke the camel's back and resulted in Jerome's first departure to the East. ${ }^{8}$

Therefore, if Priscillian and Jerome have one thing in common, apart from a very similar age, it is the charisma and ability to attract circles of Roman aristocratic women to their ranks. ${ }^{9}$ Nevertheless, according to the sources, it appears that the equality with which Priscillian treated them compared to ascetic males was one of the essential differences between him and Jerome and, at the same time, one of the many things his enemies accused him of. However, as some authors have pointed out, in this regard, Jerome's attacks on heretics are artificially rhetorical and somewhat hypocritical because they appear accompanied by women (Hier., Ep. 53.7) ${ }^{10}$ given their intense ascetic activity with their circle of Roman matrons.

7 In fact, women were the protagonists of the first forms of ascesis documented in Hispania, when they are mentioned in the Council of Elvira held at the beginning of the $4^{\text {th }}$ century as , consecrated virgins' (males ascetics would not appear in the Hispanic sources until well into the $4^{\text {th }}$ century); these female ascetics would have made a formal religious commitment under the tutelage of the ecclesiastic ministers with the sexual restraint as its basis (Marcos Sánchez 2002, 234-238). On the other hand, it is well known that Jerome wrote various treatises on female virginity, one of the most popular subjects of early Christianity, see Adkin 2003.

8 By chance, his second and definitive departure for the East was also motivated by the unfortunate consequences of the conversion to asceticism of the young widow Blaesilla, see Hier., Ep. 45. (González Salinero 2011, 543-562)

9 Well documented in the case of Priscillian is the staunch defence for him mounted by powerful aristocrats, who in turn also ended up being condemned to death (Marcos Sánchez 2002, 244-245).

10 Other works by Jerome insist on the idea of seduction of wealthy women by the leaders of the heresies, e.g. Hier., Comm. in Isaiam 17.64. 


\section{The Hispanic Ascetics Related to Jerome}

From his base in Bethlehem, Jerome consolidated his authority and continued to send letters to the Christian aristocracy of the time, which also includes a cast of Hispanic correspondents (Brogiolo 2005, 127-150; Marcos Sánchez 2014, 13-35), although we only have evidence of three: a consecrated couple and a blind ascetic. They appear in three preserved letters $(E p .71 ; 75 ; 76)$ written at the end of the $4^{\text {th }}$ century. The information is sparse, but it allows us to draw very eloquent lines of the essential nature of the first Hispanic monasticism.

Letters 71 (Ad Lucinum baeticum, a. 398) and 75 (Ad Theodoram spanam de morte Lucini, a. 399) of Jerome's epistolary corpus correspond to Lucinus and his wife, Theodora. They were wealthy landowners from Baetica (Hier., Ep. 71.3-4) ${ }^{11}$ and active euergetes for the Christian cause who had embraced the ascetic life under Jerome's influence (Marcos Sánchez 1994). Lucinus had already sent other letters (not preserved) to Jerome and six copyists to make copies of his works (Hier., Ep. 75.4). These would be the first copies of Jerome's works to arrive in Hispania.

Likewise, Lucinus had sent vast amounts of money to the churches of Jerusalem and Alexandria (75.4) and other simple but highly symbolic items. These included a piece of wool and two capes he used as proof of his renunciation of the world and his conversion to the ,perfect life' (71.7), ${ }^{12}$ a decision that had been blessed by Jerome himself when he sent four silicon garments to the Hispanic couple, endorsed in writing the orthodoxy of their practices, and invited them to establish, finally, their residence in the Holy Land (71.7).

On the other hand, in Letter 75, sent a few months later on the occasion of Lucinus' death, Jerome gave a funeral eulogy for the husband to immediately encourage Theodora to continue improving her spiritual, life of perfection' after having successfully achieved sexual continence during her last years of married life (Laurence 1997, 274-276). This letter gives clear evidence of the problem mentioned above of the heresies that were invading Hispania at that time, especially among the ascetic circles of the aristocracy: "He (Lucinus), that when the most impure heresy of Basilides was ravaging the Hispanics, and like the contagious plague was devastating all the provinces between the Pyrenees and the Ocean, was able to maintain the purity of the Church, and not admit Armazel, Barbelon, Abraxas, Balsam, or the ridiculous Luesibora or those others that, more than names of persons, are monsters invented by those heretics to impress the spirit of the ignorant and prostitutes. " (Hier., Ep. 75.3) ${ }^{13}$ Subsequently, in the same paragraph,

11 Marcos Sánchez $(2002,254)$ argues that this Hispanic husband and wife did not belong to the senatorial aristocracy, but rather to a well-off urban elite. We are going by the dates given in the 2013 Spanish translation of Jerome's epistolary by the Biblioteca de Autores Cristianos (Madrid), who based their work mainly on Migne's Latin text (PL 22 and PLS 2, 20).

12 Lucinus would have communicated to Jerome his decision to convert to the ascetic life in a letter that has not been preserved (Vilella Masana 2002, 92-93).

13 In the same letter Jerome also alludes to Gnosticism and its overwhelming success among the Hispanic aristocracy. In subsequent letters, Hieronymus described Hispanic Priscillianism as an accomplice of Gnosticism, (Hier., Ep. 133.3). The translations of the passages from Jerome's letters are taken from 
Jerome proclaims how those heterodox movements attempted, in particular, to procure for their ranks the women of ,the wealthy households'. As we have already mentioned, this is a curious reproach, given that it is merely a projection and a reflection of Jerome's strategy of surrounding himself with wealthy matrons to support his projects.

Because of their content, Ep. 71 and Ep. 75 are considered extolments to the nascent monastic life that was beginning to proliferate in Hispania according to the model of the married couple, ${ }^{14}$ withdrawing from the world and continuing to live together as a family while following rigorous patterns of continence and chastity. With their abundant economic resources - and often in their properties - they ended up sowing the seeds of authentic monasteries as they would be defined in the later literature. For this model, we have the case of the nobles Paulinus (of Gallic origin) and Tharasia (of Hispanic origin), who founded the famous Nola in a final phase of their ascetic life monasteries. We will return to Paulinus of Nola shortly.

However, the third letter sent to Hispania (Ep. 76; Ad Abigaum spanum, a. 399) briefly and concisely reveals a single person, the blind Abigaus (a priest?), perhaps also converted to asceticism under the epistolary influence of Jerome. Abigaus appears surrounded by sancti and related to an unnamed and undescribed community of a proto-monastic nature, to which some authors have indicated that the husband and wife Lucinus and Theodora may also have belonged (Vilella Masana 2002, 107). This is an exciting aspect for understanding the beginnings of the coenobitic organization at the western end of the Roman Empire. In this respect, Jerome asks Abigaus to take over the widow Theodora (Hier., Ep. 76.3).

On the other hand, also significant is the mention at the end of the letter of the journey to the Holy Land that Theodora would have begun. This was a fashionable itinerary for ascetics of the time, although, among the Hispanic women about whom we have information from the sources, she would have only been preceded by the Galician ascetic Egeria, who visited the holy sites of the East between 381 and 384 and left a written account of it.

Furthermore, here our questions arise about the structure and hierarchy of this supposed ascetic community. Would the husband and wife Lucinus and Theodora have been the estate owners on which the community came together? Therefore, would they have been the leaders of the ascetic community? Would Abigaus have been a prominent member of this community, as evidenced by his epistolary contact with Jerome? Unfortunately, all these nuances are neither indicated in the letters nor can they be deduced from them, although the first signs of a coenobitic organization that would be imposed in later centuries can be seen.

Finally, we cannot end this section concerning the letters Jerome sent to Hispania

Philip Schaff and Henry Wace, ed. 1893. Jerome: Letters and Select Works. Nicene and Post-Nicene Fathers, Second Series, Vol. 6. Buffalo, NY: Christian Literature Publishing Co. For the Latin text of Jerome's letters Hilberg's CSEL editions are used.

14 For the Late Antique marriage model, see Saje 2019. 
without mentioning Ep. 53 and Ep. 58 sent to Paulinus of Nola. Although this great poet of Christian antiquity was not Hispanic, the native of Bordeaux would indeed have begun his conversion to asceticism while living in Hispania with his wife, the Hispanic noblewoman Tharasia, ${ }^{15}$ following the death of their son, Celsus, a few days after birth between 390 and $393 .{ }^{16}$ Therefore, the ascetic model of this couple would not have been very different from that of Lucinus and Theodora.

Furthermore, thanks to Paulinus and Tharasia, we know about what we could call Jerome's ,epistolary antithesis', Ausonius of Bordeaux. Thus, just as Jerome congratulated Paulinus on his conversion and then encouraged the Baetican couple (Lucinus and Theodora) to embrace the ascetic life, in contrast, some years earlier, the poet from Bordeaux, perplexed by such a choice, was exhorting Paulinus and Tharasia to abandon that type of life and Hispania (Martínez Gázquez 1973, 30-31). In the light of the final result, the ,spiritual victor' in the epistolary contest with the ascetic couples from the Iberian Peninsula was undoubtedly Jerome. For this reason, he should be considered as one of the founders and promoters of Iberian monasticism.

Jerome's epistles have been sent to Paulinus dated 394 and 395, when the Hispano-Gallic couple relocated to their properties in Campania, near Cimitile. ${ }^{17}$ However, that does not mean that they are less attractive in terms of what we can learn from them about the asceticism practised by Christian couples in the West and Hispania.

In Ep. 53 (Ad Paulinum presbyterum, a. 394), Jerome congratulates Paulinus on his desire to enrich himself spiritually as san obedient ingenuity, still without a master, is worthy of praise « (53.3). This would have been a veiled allusion to the nascent but important monastic movement organized in the West outside the priestly hierarchies that largely contributed to expanding the aforementioned $4^{\text {th }}$ century heresies. This is why Jerome was at pains to guide Paulinus in the reading and study of the Holy Scripture (»let us study in the land that will live on in heaven « [53.10]) and invited him to come and be at his side in the Holy Land (53.11).

On the other hand, Ep. 58 (Ad Paulinum presbyterum, 395) confirms Paulinus and Tharasia's decision taken in Hispania sometime before to live a life devoted exclusively to ascesis. Therefore, Jerome exhorts Paulinus to renounce all his worldly goods completely. However, he is no longer insisting that Paulinus move to the East, as "Anthony and all the swarms of monks of Egypt and Mesopotamia, of Pontus, Cappadocia and Armenia never saw Jerusalem, and without the need for that city the gates of paradise are open to them« (58.3). However, Jerome does

15 Paulinus would have met Tharasia thanks to the divine intervention of the martyr Felix (Paul. Nol., Carm. 21.398-402).

16 The baby, born in the Hispanias, was buried alongside to martyred children (Paul. Nol., Carm. 31) in Complutum (Alcalá de Henares). Those martyrs were not named in the source but were later identified as lustus and Pastor.

17 At Christmas 394 Paulinus had been ordained priest in Barcelona, just before leaving for Italy (Paul. Nol., $E p .1 .10)$. That is why there is some debate as to whether Paulinus received $E p .53$ from Jerome while he was still in Hispania or after he arrived in Italy (Vilella Masana 2002, 87-88). 
recommend "that you renounce the city and do not abandon your vocation as a monk « (58.4) if he finally decides not to practice as a presbyter. He also recommends that he distance himself from the masses and the powerful, as well as eating meagre, vegetarian meals and practising other recommendations of austerity and contention along the lines that would be followed by Lucinus and Theodora a few years later (58.6-7).

Jerome's letters directly impacted Hispania, but part of his non-epistolary literary work also influenced subsequent monasticism. ${ }^{18}$ For example, the Vita Pauli influenced the drawing up of the Vita Fructuosi (Díaz y Díaz 1974, 28), the famous monk and bishop of Braga who organized the monastic life of the northwestern quadrant of the Iberian Peninsula during the $7^{\text {th }}$ century, founding numerous monasteries and writing the rules for them.

Concerning Hispania and its incipient monasticism, we should also mention the Adversus Vigilantium, a treatise written by Jerome in 406 in response to the critical views that Vigilantius, a priest from Barcino, ${ }^{19}$ had monasticism and other fundamental elements of Christianity, such as the worship of saints and relics. His criticism of monasticism derived from his complete rejection of celibacy, a mainstay of asceticism for Jerome and in the official position of the Church. Vigilantius did not accept the monk's view as, from his perspective, it represented an escape from society (Hier., Adv. Vigil. 356-357). Once in Barcelona, where he would have arrived between 406 and 408 fleeing from the Vandal invasions (Massie 1980, 94-96), Vigilantius continued to defend his postulates (Castellanos 1995-96, 416-418).

\section{Some Archaeological Notes}

From other letters written by Jerome, it can be deduced that this Hispanic aristocracy probably built other domestica ecclesia on their properties, as documented for example in Ep. 30, which refers to the construction of a domestic church to host an ascetic community in the house of the Roman matron Paula (30.14).

We could already be looking at domestica monasteria, as documented half a century later in the Council of Ilerda (present-day Lleida) in 546, which would anathemise the monasteries founded by private individuals that were not subjected to the authority of the diocese (Conc. Ilerdensis, c. III.). More than a century later, the Regula communis, probably written by Fructuosus of Braga, insisted on that subject and specified the existence of monasteries consecrated in private homes. ${ }^{20}$

18 However, Monaci Castagno noted that Jerome never wrote neither ecclesiastical history nor a monastic history, nonetheless he cultivated the ambition to be a historian of the Church or monasticism (2011, 22).

19 Vigilantius was of Aquitanian origin (Hier., Adv. Vigil. 355ss.) and news of his appointment in Barcelona was provided by Gennadius of Marseille (Gennad., De vir. ill. 36).

20 »Indeed, some are accustomed to organising monasteries in their own homes for fear of hell, and to gather in community with their wives, children, servants and neighbours under the firmness of oath, 
There are quite a few Roman villae in Hispania in which slightly later chapels are documented ( $5^{\text {th }}-7^{\text {th }}$ cent.) (Chavarria Arnau 2007, 143-152; Brogiolo 2005, 130-132) that could already have been fulfilling this function in the last quarter of the $4^{\text {th }}$ century. We have some archaeological remains of a sizeable late-Roman villae in southern Hispania for which we do not know the names of the former owners, but that could have easily belonged to ascetic married couples or another kind of family circle from the end of the fourth century.

Roman villas such as La Cocosa (Badajoz), La Olmeda (Palencia), El Saucedo (Toledo) or Milreu (Estoi, Portugal) could have been Christian monasteries or retreats for aristocratic ascetics during their late imperial phase. This possibility is based on the presence of basilicas in each of them. However, it is hazardous to go further and deduce only from that archaeological evidence that the ancient buildings in Roman villas were occupied by ascetics and/or monks or whether, in contrast, the villa basilicas were merely private chapels built for the owners. There is also a possibility that both cases could have occurred, correlatively, in individual villas. The private chapel could have attracted a community of monks, all without excluding the following parochial functions.

All these possibilities and questions can be applied to many archaeological sites. The paradigm could perhaps be the Villa Fortunatus (Fraga, Huesca), where, on one side of the peristyle, a chapel with a baptismal pool and a necropolis were installed in the $5^{\text {th }}$ century (Navarro Sáez 1999, 147-150). All this in a villa whose proprietor was already a Christian in the third quarter of the $4^{\text {th }}$ century, according to a mosaic excavated in the domestic area.

Along the same lines of discussion but introducing more recent stratigraphic levels, of particular interest are various medieval monasteries or late antiquity churches that, interestingly, are built on the remains of Roman villas. For example, at the site known as Monte do Mosteiro (Mértola, Portugal), there is an early medieval church on the plot of a Roman villa (Maciel and Martins 1995, 499-506). Moreover, at Sítio do Mosteiro (S. Bartolomeu do Outeiro, Portugal), a Visigothic basilica was excavated in a Roman villa with several chronological phases (Alfenim and Lima 1995, 463-469). It is likely that the toponym ,monastery' in these places (documented as early as the Middle Ages) refers to a monasterium in villa?

Therefore, the archaeological examples mentioned could have their origin as monasteries in the early ascetic practices of a private family nature, such as those undertaken in their villas by the Hispanic and Hispano-Gallic couples, is documented in Jerome's letters. 


\section{Conclusion}

Jerome shows us how Hispanic monasticism was born and spread among the aristocracy due to the influence of literature (in this case, the epistolary genre) at a time when it was a practice restricted to matrimonial and/or family circles. Jerome addresses his letters to that aristocracy to answer their doctrinal doubts and lead them on the straight path of heterodoxy at a time of convulsion caused by heretical disputes that ravaged both East and West. The Hispanic monasticism that came later - progressively more plural and heterogeneous on a social level - would be regulated based on coenobitic rules designed for community life and promoted by what had already become local episcopal hierarchies. Meanwhile, the formation of communities would soon be disassociated from their origin in the nuclei of aristocratic married couples converted to asceticism that abounded in the last years of the $4^{\text {th }}$ century.

However, the substrate of the Hieronymian seed in Hispanic monasticism would survive the passage of time, with not only the influence of his work remaining indelible but also its invocation in many monasteries and monastic landscapes. For instance, in Montserrat's millenary monastery (north-eastern Hispania), the highest peak on the mountain, where it is set, has been dedicated to St Jerome.

The saint's popularity on the Iberian Peninsula would be crystallized in creating the Order of Saint Jerome in the $14^{\text {th }}$ century (after a brief formation stage of an eremitic nature) foundation of successive Hieronymian monasteries during the years immediately after. These included San Bartolomé de Lupiana (Guadalajara), the true germ of the Order; San Jerome de Yuste (Cáceres); Sant Jeroni de la Vall d'Hebron (Barcelona); and Sant Jeroni de la Murtra (Badalona) (Díaz Martí, 2006). ${ }^{21}$

Nevertheless, it is in the south of the Iberian Peninsula that the Hieronymian monastic order appears to have taken root most extensively and intensively, especially in Andalusia:22 San Jerónimo de Valparaíso, in Córdoba, now declared a National Monument; or San Jerónimo de Buenavista in Seville; and eloquently, the first monastery built in Granada after the Catholic monarchs had taken the Muslim town, was one dedicated to St. Jerome (which appears to have an earlier history, although it is very poorly known). For their part, the female Hieronymian congregations, such as Santa Paula in Seville, Santa María de la Asunción in Morón de la Frontera, Nuestra Señora de los Ángeles in Constantina, Santa Marta in Córdoba, and Santa Paula in Granada, remind us of the importance of female spirituality in Jerome's monastic doctrine.

So, it should be noticed that it was in southern Spain - ancient Baetica (where Lucinus, Theodora, and Abigaus lived and practised ascesis) - that coincidentally it appears that Jerome's name associated with the monastic world was recov-

21 Although it is currently cloistered, this monastery is spiritually and culturally still very active.

22 Hernández-Díaz Tapia also emphasises the importance of the female branch of the Hieronymian order in Andalusia (1976, 7). 


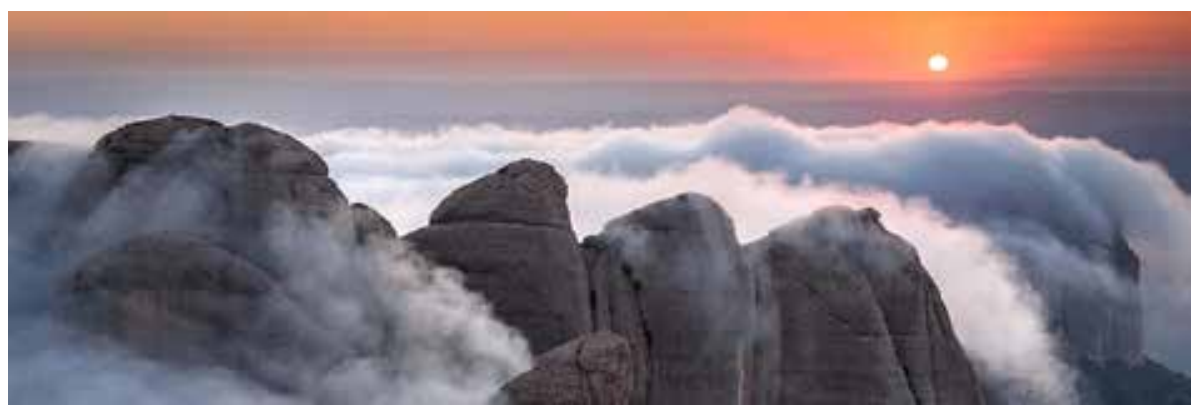

Photo 2: The highest peak - dedicated to St. Jerome - of the mountain that hosts the monastery of Montserrat (Barcelona), dedicated to St. Jerome (photo: Sergi Boixader).

ered with greater intensity from the time of the Christian advance that ended up expelling the Muslims from ancient Hispania. This leads us to suspect that the Hieronymian legacy would have been transmitted powerfully from antiquity and survived during the long interval of Muslim occupation.

\section{Abbreviations}

Adv. Vigil. - Adversus Vigilantium.

CSEL - Corpus Scriptorum Ecclesiasticorum Latinorum.

De vir. ill. - De Viris Illustribus.

Ep. - Epistulae.

PL - Patrologia Latina.

\section{References}

\section{Primary sources}

Coustant, Pierre, ed. 1845. Sancti Siricii Papae: Epistulae et decreta. PL 13. Paris: Petit-Montrouge, J.-P. Migne.

Díaz y Díaz, Manuel C, ed. 1974. La vida de San Fructuoso de Braga: Estudio y edición crítica. Braga: Diário do Minho.

Hillberg, Isidor, ed. 1996. S. Eusebii Hieronymi Opera: Epistularum. Vol. 2, Epistulae: LXXICXX. CSEL 54. Vienna: Verlag der Österreichischen Akademie des Wissenschaften.

\section{Secondary sources}

Adkin, Neil. 2003. Jerome on Virginity: A Commentary on the Libellus de virginitate servanda (Letter 22). Cambridge: Francis Cairns Publications.

Alfenim, Rafael A. E., and Paulo Lima. 1995. Bre- ve notícia sobre a campanha arqueológica de 1992 na igreja visigótica do Sítio dos Mosteiros, Portel. In: Josep M. Gurt and Núria Tena, ed. IV Reunió d'Arqueologia Cristiana Hispana, 463-469. Barcelona: Institut d'Estudis Catalans (Universitat de Barcelona).

Bautista Valero, Juan. 2013. Introducción. In: San Jerónimo. Obras completas. Vol. 10. Epistolario, I-cartas 1-85**, 19-93. Madrid: Biblioteca de Autores Cristianos.

Brogiolo, Gian Pietro, and Alexandra Chavarria Arnau. 2005. Aristocrazie e champagne nell'Occidente da Costantino a Carlo Magno. Florence: All'Insegna del Giglio.

Castellanos, Santiago, and del Txomín Pozo. 1995-96. Vigilancio y el culto a los santos y sus reliquias en el Occidente tardoantiguo. Studia Historica: Historia Antigua 13-14: 405-420.

Chavarría Arnau, Alexandra. 2007. El final de las villae en Hispania (siglos IV-VIII). Turnhout: 
Brepols.

Díaz Martínez, Pablo de la Cruz. 1991. La recepción del monacato en Hispania. Codex aquilarensis: Cuadernos de investigación del Monasterio de Santa María la Real, no. 5:131-140.

Escribano Paño, M. Victoria. 1990. Herejía y poder en el s. IV. In: La conversión de Roma. Cristianismo y paganismo, 151-189. Eds. Candau, José María, Fernando Gascó, and Antonio Ramírez de Verger. Madrid: Ediciones Clásicas.

Fontaine, Jacques. 1979. L'aristocratie occidentale devant le monachisme aux IV et $V^{e}$ siècles. $R i$ vista di Storia e Letteratura Religiosa 15:28-53.

González Salinero, Raúl. 2011. Ocio y ascesis aristocrática: Jerónimo y su ,lectio divina' en Roma (382-385). Espacio, Tiempo y Forma. Serie II, Historia Antigua 24:543-562. https://doi. org/10.5944/etfii.24.2011.1879

Hernández-Díaz Tapia, M. Concepción. 1976. Los monasterios de Jerónimas de Andalucía. Sevilla: Publicaciones de la Universidad de Sevilla.

Jeanjean, Benoît. 1999. Saint Jérôme et l’hérésie. Paris: Institut d'Études Augustiniennes.

Laurence, Patrick. 1997. Jérôme et le nouveau modèle féminin: La conversion à la ,vie parfaite'. Paris: Institut d'Études Augustiniennes.

Maciel, Manuel Justino, and Joao Paulo Martins. 1995. Monasterium e ecclesia de S. Salvador no Monte do Mosteiro (Mértola). In: Josep M. Gurt and Núria Tena, eds. IV Reunió d'Arqueologia Cristiana Hispana, 499-506. Barcelona: Institut d'Estudis Catalans (Universitat de Barcelona).

Marcos Sánchez, Mar. 1994. Aristocracia y cristianismo en la Hispania tardoantigua: la conversión de Lucinio y Teodora. In: III. Congreso Peninsular de Historia Antigua. Preactas. Vol. 2, 778-784. Vitoria: Universidad del País Vasco/ Departamento de Estudios Clásicos.

- - - 2002. El ascetismo y los orígenes de la vida monástica. In: Ramón Teja, ed. La Hispania del siglo IV.: Administración, economía, sociedad, cristianización, 231-266. Bari: Edipuglia.

- - - 2014. Monacato y aristocracia en los comienzos del cristianismo. In: José A. García de Cortázar and Ramón Teja, eds. Monasterios y nobles en la España del Románico: entre la devoción y la estrategia, 13-35. Aguilar de Campoo: Fundación Santa María la Real.
Martínez Gázquez, José. 1973. Paulino de Nola e Hispania. Boletín del Instituto de Estudios Helénicos 7, no. 2:27-33.

Massie, Michel. 1980. Vigilance de Calagurris face a la polémique hiéronymienne: Les fondements et la signification du conflit. Bulletin de littérature ecclésiastique 81:81-108.

Monaci Castagno, Adele. 2011. Primus in primis: Gerolamo, storico del monachesimo. Adamantius 17:10-22.

Moreschini, Claudio. 1982. II contributo di Girolamo alla polemica antipelagiana. Cristianesimo nella Storia 3:61-71.

Navarro Sáez, Rosario. 1999. Villa Fortunatus. In: Pere de Palol, ed. Del Romà al Romànic: Història, art i cultura de la Tarraconense mediterrània entre els segles IV i X, 146-150. Barcelona: Gran Enciclopèdia Catalana.

Saje, Andrej. 2019. Sklepanje krščanskega zakona na Zahodu in Vzhodu od pozne antike do zgodnjega srednjega veka [Celebration of Christian Marriage in the West and East from the Late Roman to the Early Medieval Period]. Bogoslovni vestnik 79, no. 4:989-1000. https://doi. org/10.34291/bv2019/04/saje

Vilella Masana, Josep. 2002. Los corresponsales hispanos de Jerónimo. Sacris Erudiri 41:87-111. https://doi.org/10.1484/j.se.2.300488 